\title{
PENGUKURAN INFILTRASI TANAH BUKIT PINANG-PINANG KAWASAN HUTAN HUJAN TROPIK GUNUNG GADUT PADANG DI LABORATORIUM
}

\author{
Yulnafatmawita, Asmar, Ricci Enrella \\ J urusan Tanah F ak. Pertanian U nand Padang
}

\begin{abstract}
A research about infiltration rate of soils from Pinang-Pinang area, a super wet tropical rain forest gunung Gadut Padang, was conducted in soil laboratory Agriculture Faculty, Andalas University. Pinang-pinang area is located in Kecamatan Pauh, in the upper footslope of Gadut mountain, functiong as water regulation for the area down under, especially Padang city. This is caused by the fact that water from the Pinang-Pinang area will fow to the sea through Kuranji river. This area is supposed to be protected to avoid natural disaster in the area down under. This research was aimed to determine infiltration rate of soils under different land use in the Pinang-Pinang region. There were three land use in this area, forest, mixed garden, and bush. Undisturbed soil samples were taken from each land use by using $11-\mathrm{cm}$ in diameter and $40 \mathrm{~cm}$ height tubes. Soils samples were tightly closed, and brought into laboratory. Infiltration rate from each soil samples were determined in laboratory. The results showed that mixed garden gave the highest infiltration rate $\left(38.4 \mathrm{~cm} \mathrm{jam}^{-1}\right)$ among the land use tested, and then followed by forest land use, and then bush land.
\end{abstract}

Key Words: infiltration, land use, tropical rain forest

\section{PENDAHULUAN}

Hutan berperan sebagai sumber daya alam yang harus dipertahankan keberadaannya. Hutan bukan saja sebagai sumber papan, sumber keragaman hayati, dan sebagainya, tetapi juga sebagai pengatur hidrologi suatu kawasan. Hal ini disebabkan karena hutan mampu menampung air hujan dan menyimpannya di dalam profil tanah, yang selanjutnya dikeluarkan ke daerah sekitar dan di bawahnya sedikit demi sedikit secara kontnyu. Dengan demikian, daerah aliran sungai tidak akan mengalami kebanjiran di musim hujan dan kekeringan di musim kemarau.

Secara alami lahan hutan mempunyai kondisi fisik yang berbeda dari lahan lainnya. Pada hutan terdapat biopores yang disebabkan oleh kehidupan fauna tanah dan akar tanaman, serta lapisan serasah. Kedua faktor ini, biopore dan serasah, sangat menguntungkan karena lapisan serasah akan berfungsi sebagai penahan tumbukan butir hujan pada tanah, sedangkan biopores berperan untuk meloloskan air hujan yang jatuh dipermukaan kedalam profil tanah. Akibatnya laju infiltrasi dapat dipertahankan, dan aliran permukaan (run off) dapat diminimalisir (Hairiah et al., 2004).

Pembukaan hutan akan mengubah perannya bagi lingkungan, diantaranya sebagai pengatur hidrologi. Hal ini disebabkan oleh perubahan proses fisika, kimia, dan biologi pada tanah akibat pembukaan lahan. Salah satu proses yang signifikan terjadi adalah penumpukan dan dekomposisi bahan organik tanah. Akibat pembukaan hutan, sumber bahan organik berkurang sedangkan laju perombakan bahan organik meningkat dari biasanya. Hal ini disebabkan oleh meningkatnya suhu permukaan tanah karena cahaya matahari langsung mencapai tanah. Selanjutnya, disamping tidak adanya kanopi tanaman yang mampu mereduksi energi kinetik butir hujan, terdekomposisinya serasah mengakibatkan air hujan yang jatuh selama musim penghujan langsung memukul permukaan tanah. Hal ini berakibat pecahnya dan bahkan terdispersinya agregat tanah. Butir halus tanah akan menyumbat pori yang mengakibatkan kecepatan masuknya air ke dalam tanah atau disebut dengan laju infiltrasi tanah menurun. Jika kecepatan jatuhnya butir hujan melampaui 
laju infiltrasi tanah, maka akan terjadi aliran permukaan (run off) yang sekaligus mengangkut partikel tanah yang sudah terdispersi dan bahan-bahan lain termasuk bahan organik (erosi) ke bagian yang lebih rendah.

Bukit Pinang-Pinang adalah salah satu kawasan hutan hujan tropik yang terletak di kaki bagian atas gunung Gadut dengan altitude $\pm 550 \mathrm{~m} \mathrm{dpl}$. Daerah ini secara administratif termasuk kecamatan Pauh kota Padang Sumatra Barat. Curah hujan di daerah ini relatif tinggi yaitu 6500 mm per tahun, tanpa musim kering yang nyata (Rasyidin dan Wakatsuki, 1994). Bukit Pinang-Pinang ini dilalui oleh dua sungai Batang Lantiak dan Sungai Gaduik Gadang. Kedua sungai ini bersatu menjadi Batang Kuranji yang bermuara di samudra Indonesia melalui kota Padang, ibu kota propinsi Sumatera Barat. Jadi kawasan Pinang-Pinang berfungsi sebagai pengatur hidrologi kota Padang. Oleh sebab itu, kawasan ini perlu dipertahankan agar tingkat erosi rendah, antisipasi banjir pada musim hujan, dan kekeringan pada musim kemarau.

Akan tetapi, maraknya illegal logging akhir-akhir ini telah mengubah ekosistem hutan menjadi ekosistem lainnya. Pada lahan yang relatif datar (slope antara 3$8 \%$ ) sudah mulai ditebang sejak limapuluhan tahun yang lalu. Daerah ini dimanfaatkan oleh penduduk sekitarnya untuk menanam tanaman tua seperti durian, manggis, duku, dan coklat, serta beberapa tanaman muda seperti pisang, ubi kayu yang bisa mereka panen diantara musim buah atau sebelum tanaman tua di panen. Daerah ini kita kenal sebagai daerah kebun campuran. Selanjutnya, pembukaan lahan pada altitude yang lebih tinggi tidak dimanfaatkan lagi oleh penduduk untuk bertani. Hal ini disebabkan oleh luasan yang sempit dan mempunyai lereng yang sudah agak curam (slope $>15 \%$ ). Daerah ini ditumbuhi oleh tanaman berkayu yang rendah serta semak, seperti rimbang (M elastoma Sp), krinyuh (C.odorata) paku resam, dsb., sehingga daerah ini dikenal dengan semak belukar.

Akibat illegal logging di daerah Bukit Pinang-Pinang ini, maka diperoleh tiga macam penggunaan lahan, yaitu hutan $(\mathrm{H})$, kebun campuran $(\mathrm{KC})$, dan semak belukar (SB). Apakah perubahan penggunaan lahan dari hutan menjadi kebun campuran dan semak belukar mengubah peran dari kawasan Pinang-Pinang ini sebagai pengatur hidrologi, dirasa perlu untuk dikaji. Salah satu parameter yang dapat diukur untuk mengevaluasi peran hutan sebagai pengatur hidrologi yaitu laju dan kapasitas infiltrasi tanahnya.

Infiltrasi adalah suatu istilah yang diterapkan pada proses masuknya air kedalam tanah umumnya oleh aliran ke bawah melalui seluruh atau sebagian dari permukaan tanah. Kecepatan proses ini relatif terhadap kecepatan pemberian air, sehingga akan menentukan berapa banyak air yang memasuki zona perakaran serta berapa banyak yang akan menjadi aliran permukaan. Oleh sebab itu, kecepatan infiltrasi bukan saja mempengaruhi pengaturan air bagi lingkungan tanaman, tetapi juga jumlah aliran permukaan dan bahaya terjadinya erosi tanah. Bila proses infiltrasi terhambat, maka resapan air berkurang, sedangkan jumlah aliran permukaan yang akan menyebabkan erosi tanah akan bertambah. Oleh sebab itu, pengetahuan tentang proses erosi yang dipengaruhi oleh sifat-sifat tanah serta cara pemberian air merupakan suatu syarat pengelolaan tanah secara efisien (Hillel, 1982).

Laju maupun kapasitas infiltrasi merupakan parameter yang penting dalam upaya mengetahui tingkat erosi suatu lahan. Hal ini berhubungan dengan besar kecilnya aliran permukaan yang terjadi. Di samping itu, infiltrasi penting untuk ketersediaan air tanah bagi tanaman, pengisian air bawah tanah dan penyediaan aliran pada sungai di musim kemarau. Sehingga informasi tentang infiltrasi sangat diperlukan (Hillel, 1982). Oleh sebab itu, penelitian ini dilakukan bertujuan untuk mengetahui laju infiltrasi yang terjadi pada masing-masing penggunaan lahan di daerah Pinang-Pinang, kawasan hutan hujan tropik Gunung Gadut Padang yang pengukurannya dilakukan di laboratorium. 


\section{BAHAN DAN METODA}

Pengukuran infiltrasi ini seharusnya dilakukan lansung di lapangan, yaitu dengan menggunakan alat double ring infiltrometer. Akan tetapi, karena jarak lokasi penelitian jauh dari sumber air dan sulitnya medan untuk pengangkutan air ke lokasi penelitian (puncak bukit), maka penelitian dilakukan di laboratorium. Sampel tanah utuh dilapangan diambil dengan cara menggunakan paralon berukuran diameter $11 \mathrm{~cm}$ dan tinggi $40 \mathrm{~cm}$. Tanah diambil sampai kedalaman tanah 30 $\mathrm{cm}$, karena pada kedalaman tersebut sudah ditemui batuan dan kerikil yang menghalangi masuknya paralon ke dalam tanah. Sampel tanah ditutup pada kedua ujung paralon dan kemudian dibawa ke laboratorium. Penelitian ini dilakukan dengan menggunakan metoda survai. Pengambilan contoh tanah dilakukan secara "Purposive Random Sampling" yaitu berdasarkan penggunaan lahan. Dalam hal ini, pengambilan contoh tanah dilakukan pada 3 penggunaan lahan (hutan, kebun campuran, dan semak belukar). Masingmasing penggunaan lahan diukur laju infiltrasinya.

Cara pengambilan sampel tanah utuh di lapangan dan pengukuran infiltrasi di laboratorium ditampilkan dalam uraian berikut:

a. Terlebih dahulu lokasi yang akan diukur dibersihkan dari rumput dan bahan organik segar.

b. Paralon diletakkan pada tempat dimana tanah akan diambil, lalu tanah sekeliling paralon digali sehingga tanah yang berada di bawah paralon bisa masuk ke dalam paralon.

c. Kemudian paralon yang sudah berisi tanah tadi ditutup ujung pangkalnya dengan plastik dan dibawa ke laboratorium.

d. Air disiapkan secukupnya di laboratorium demikian pula stop watch dan alat tulis e. Pada dinding paralon bagian dalam diberi skala, ditarik dua garis dengan jarak $10 \mathrm{~cm}$. Sehingga didapat garis batas atas dan garis batas bawah.

f. Kemudian tanah diairi sampai air mencapai garis batas atas.

g. Jarak penurunan air berdasarkan interval waktu dicatat sampai air yang terinfiltrasi konstan. Yaitu sampai waktu yang diperlukan oleh muka air turun sampai garis batas bawah punya interval yang sama

h. Laju serta kapasitas infiltrasi selama pengukuran dihitung

Hasil pengukuran laju infiltrasi belum dapat digunakan untuk menduga laju infiltrasi pada waktu yang diinginkan. Hal ini karena pengukuran infiltrasi dengan alat ukur infiltrasi ini ada kelemahan-kelemahan yaitu, (1) tidak adanya efek butir air hujan yang mengakibatkan pemadatan dan penyapuan bahan halus, (2) tidak adanya efek tekanan udara. Oleh karena itu diperlukan suatu pendekatan yang dianggap lebih mendekati dengan keadaan lapangan. Dalam hal ini degunakan pendekatan model Horton (1940 cit Hillel 1982), yang persamaannya ditulis sebagai berikut :

$$
\begin{aligned}
& \mathrm{f}=\mathrm{fc}+(\mathrm{fo}-\mathrm{fc}) \times \mathrm{e}^{-\mathrm{kt}} \\
& \mathrm{I}=\mathrm{fct}+\frac{(\mathrm{fo}-\mathrm{fc})}{\mathrm{k}} \times \mathrm{e}\left(1-\mathrm{e}^{-\mathrm{kt}}\right) \\
& \mathrm{f}=\text { Laju infiltrasi (mm/jam) } \\
& \mathrm{fo}=\text { Laju infiltrasi awal (mm/jam) } \\
& \mathrm{fc}=\text { Laju infiltrasi tetap / konstan } \\
& \mathrm{t} \quad \text { (mm/jam) } \\
& \mathrm{k} \quad=\text { waktu ( menit }) \\
& \mathrm{e} \quad=2,718 \\
& \mathrm{I} \quad=\text { Kunstanta geofisik }
\end{aligned}
$$




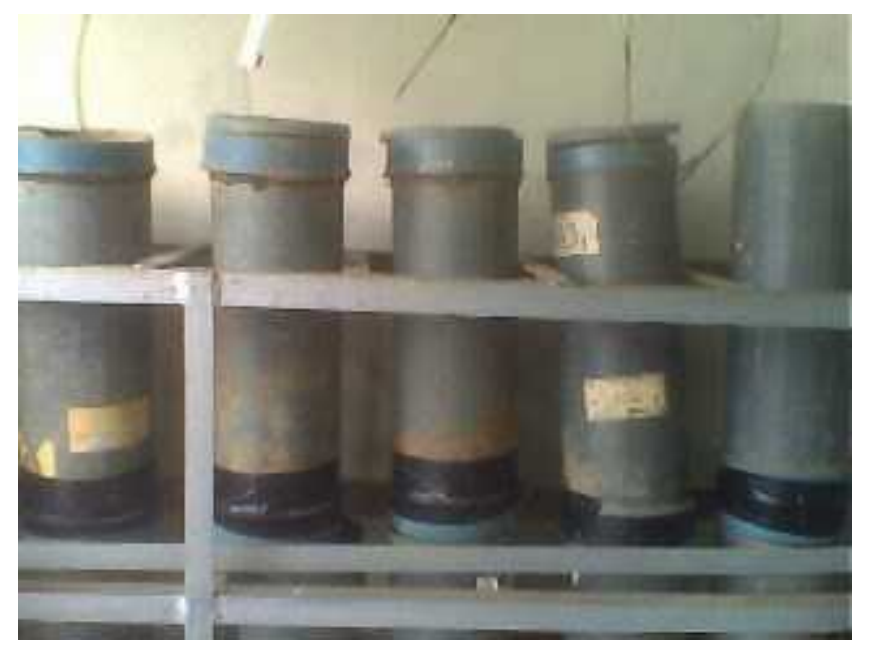

Gambar 2: Alat pengukur infiltrasi di laboratorium.

Data yang diperoleh dari pengukuran infiltrasi merupakan infiltrasi nyata. Kemudian data tersebut dimasukkan ke dalam rumus Horton, (1940) Lampiran 5. Hasil atau data infiltrasi ini diplot ke dalam grafik. Nilai infiltrasi yang sudah dimasukkan dalam rumus Horton dibandingkan dengan kriteria infiltrasi menurut Kohnke (1968 cit Lee, 1998) pada Lampiran 6.

\section{HASIL DAN PEMBAHASAN}

\section{Keadaan Umum Daerah Penelitian}

Daerah penelitian ini berada pada posisi antara $100^{\circ} 29^{\prime} 40^{\prime \prime}$ dan $100^{\circ} 30^{\prime} 20^{\prime \prime}$ BT serta antara $0^{\circ} 54^{\prime} 55^{\prime \prime}$ and $0^{\circ} 55^{\prime} 45^{\prime \prime} \mathrm{LS}$, dengan ketinggian 390-560 $\mathrm{m}$ diatas permukaan laut. Curah hujan tahunan lebih dari $6500 \mathrm{~mm}$ dan tidak ada musim kering yang nyata (Rasyidin dan Wakatsuki, 1994). Ordo tanah daerah penelitian ini termasuk Inceptisol dengan bentuk fisiografinya kipas alluvium dan memiliki bahan induk yang umumnya berupa rombakan andesit dari gunung api. Pada bagian puncak bukit terdapat tiga tipe subgroup tanah yaitu Typic Dystropepts, Lithic Dystropept, dan Lithic Eutropepts dan dibagi lagi dalam tujuh famili tanah (Hermansah et al., 2000).

Daerah penelitian ini mempunyai karakteristik iklim monsoon (musim hujan) tropik basah dengan rata-rata suhu tahunan $27^{\circ} \mathrm{C}$ dengan perbedaan suhu yang relatif kecil dari $2^{\circ} \mathrm{C}$ antara musim hujan dan musim kemarau Kelembaban relatif setiap bulan adalah $73 \%$ - $80 \%$ dengan rata-rata kelembaban tahunan adalah $77 \%$ (Ogino, 1994).

\section{Sejarah Penggunaan Lahan}

Dari hasil pengamatan di lapangan dan data yang diperoleh dari masyarakat sekitar pada survai awal diketahui bahwa pada hutan hujan tropis Bukit Pinang-Pinang terdapat tiga penggunaan lahan yaitu kebun campuran,semak belukar, dan hutan.

\section{Kebun Campuran}

Kebun campuran merupakan suatu lahan yang berasal dari hutan yang ditinggalkan setelah ditebang, kemudian ditanami oleh masyarakat dengan tanaman tahunan untuk menambah pendapatan masyarakat. Pada kawasan Bukit PinangPinang ini, lahan yang dijadikan kebun campuran pada umumnya ditemui pada daerah kaki bukit, yaitu lahan pada ketinggian 390-398 $\mathrm{m}$ dpl dengan kelerengan 3\% hingga 8\%, dan luas sekitar 10,72 hektar, yaitu $11,18 \%$ dari luas Pinang-Pinang. Pada kawasan ini terdapat tanaman manggis ( $G$ arcinia mangostana, L), durian (Durio zibetinus), dan coklat (Theobroma cacao, L) sebagai tanaman tua serta pisang (Musa, sp) dan ubi kayu (M anihot uttilissima) sebagai tanaman muda. 
Tanaman pisang dan ubi kayu dapat dipanen penduduk diantara panen tanaman tua.

Disamping ditanami dengan tanaman budidaya yang berproduksi, tanah pada lahan ini juga ditumbuhi oleh tumbuhan liar yang tumbuh secara alami dipermukaan tanah (understorey plants). Vegetasi yang tumbuh pada lahan ini didominasi oleh rumput-rumputan (Graminae sp) , keladi (Caladium sp), anggrek tanah (Orchidaceae sp), krinyuh (Caladium surinameuse), dan sebagainya. Dengan demikian, permukaan lahan tidak ada yang terbuka atau dengan kata lain tanaman liar yang tumbuh berperan sebagai penutup tanah. Tanaman penutup tanah tersebut di pangkas secara reguler, khususnya ketika saat panen tanaman pokok akan dilakukan. Oleh sebab itu, pengembalian bahan organik ke dalam tanah lebih cepat dan berlanjut dari waktu ke waktu.

\section{Semak Belukar}

Pada umumnya lahan semak banyak terdapat pada lahan-lahan bekas penebangan hutan yang baru dibuka $(<20$ tahun yang lalu), tetapi tidak ditanami oleh masyarakat sehingga dibiarkan terbuka. Daerah ini tidak bisa dijadikan lahan perkebunan, karena pada umumnya lahan ini punya kendala kelerengan yang curam ( $\geq$ $40 \%$ ) dan luasan yang sempit di pinggang bukit (pada ketinggian 480-495 m). Semakin banyak terjadi penebangan hutan di lereng yang curam maka lahan semak akan semakin luas. Berdasarkan peta topografi dan peta penggunaan lahan dapat dilihat luas lahan semak ini 21,80 Ha yaitu 22,44\% dari total luas Bukit Pinang Pinang. Lahan yang sudah lama ditinggalkan setelah penebangan ditumbuhi oleh tanaman semak yang sangat rimbun. Tumbuhan yang tumbuh pada lahan semak ini diantaranya krinyuh (Caladium surinameuse), jelatang, sikaduduak (Melastoma malabatricum), paku resam (Gleicenia linearis), linju, pandan, rimbang dan tanaman semak lainnya

Hutan
Hutan pada kawasan Bukit Pinang Pinang masih tergolong hutan primer, tetapi telah banyak ditebang secara liar oleh masyarakat sekitar, sehingga pohon-pohon yang berdiameter besar sudah mulai jarang ditemui. Ciri-ciri hutan seperti terdapatnya pepohonan yang berkanopi cukup rapat serta masih ditemukan sarasah yang cukup tebal $( \pm 5 \mathrm{~cm}$ pada permukaan tanah) masih ditemukan di kawasan ini. Lantai hutan bersih dari pohon atau tanaman rendah karena ilim mikro di bawah hutan ini tidak memungkinkan tumbuhnya tanaman. Suhu permukaan tanah juga terasa lebih dingin dari daerah di luar hutan.

Berdasarkan peta penggunaan lahan, kawasan lahan hutan ditemui pada ketinggian 480-495 m (pinggang bukit) dan pada $550 \mathrm{~m}$ dpl (puncak bukit), dengan ukuran paling luas dibandingkan penggunaan lahan lainnya, yaitu $\pm 63,96 \mathrm{Ha}$ $(66,43 \%)$ dari keseluruhan luas bukit Pinang Pinang. Ttapi, hutan ini juga umumnya punya kelerengan > 40\%. Perubahan penggunaan lahan hutan ini disebabkan karena pada kawasan ini telah terjadi penebangan hutan secara liar oleh masyarakat, baik diambil kayunya untuk dijual maupun untuk kebutuhan sehari-hari (sebagai kayu bakar) ataupun untuk dijadikan lahan pekebunan.

\section{Laju Infiltrasi Tanah Pada Masing- Masing Penggunaan Lahan}

Hasil penetapan laju infiltrasi pada daerah Pinang-Pinang kawasan hutan hujan tropik Padang dapat dilihat pada Tabel 1.

Dari Tabel 1 dapat dilihat bahwa laju infiltrasi nyata tanah berbeda menurut kriteria pada masing-masing penggunaan lahan. Terjadinya perbedaan laju infiltrasi tanah tersebut disebabkan oleh beberapa hal diantaranya perbedaan vegetasi yang tumbuh di atasnya dan kondisi tanah. Kondisi tanah yang dapat mempengaruhi diantaranya tekstur tanah, kandungan bahan organik, berat volume, total ruang pori, dan kadar air tanah. 
Tabel 1. Hasil penetapan laju infiltrasi daerah Pinang-Pinang kawasan hutan hujan tropik Gunung Gadut Padang.

\begin{tabular}{cccc}
\hline No & Penggunaan Lahan & $\begin{array}{c}\text { Laju Infiltrasi } \\
\mathrm{mm} / \mathrm{jam}\end{array}$ & Kriteria \\
\hline 1 & Hutan & 154.48 & Cepat \\
2 & Kebun Campuran & 384.22 & Sangat Cepat \\
3 & Semak Belukar & 96.45 & Sedang Cepat \\
\hline
\end{tabular}

Besarnya laju infiltrasi tanah erat hubungannya dengan tekstur tanah. Pada tabel terlihat bahwa penggunaan lahan kebun campuran mempunyai laju infiltrasi nyata sangat cepat $(384,22 \mathrm{~mm} / \mathrm{jam})$, yaitu melebihi $( \pm 250 \%)$ laju infiltrasi pada ekosistem hutan. Sedangkan laju infiltrasi tanah pada penggunaan lahan semak belukar lebih rendah $( \pm 62 \%)$ dari ekosistem hutan. Berdasarkan hasil penelitian Yulnafatmawita et al (2007), tekstur tanah pada hutan yaitu lempung liat berdebu, pada semak belukar antara liat-liat berdebu, sedangkan pada kebun campuran berkisar antara kelas lempung-lempung berdebu. Dari ke tiga jenis penggunaan lahan tersebut tekstur tanah pada kebun campuran lebih kasar dari hutan, dan hutan lebih kasar dari semak belukar. Jadi jelaslah bahwa semakin kasar tekstur tanah, maka semakin cepat masuknya air dari permukaan ke dalam profil tanah. Hal ini disebabkan oleh banyaknya jumlah pori makro yang dijumpai pada tanah bertekstur kasar dibanding tanah bertekstur halus.

Selain tekstur, kandungan bahan organik tanah mempunyai pengaruh yang besar terhadap laju infiltrasi. Pada kondisi teksur yang sama, laju infiltrasi tanah akan berbeda akibat perbedaan bahan organik tanahnya. Lahan hutan dan semak belukar yang mempunyai tekstur hampir sama tapi laju infiltrasi pada lahan hutan lebih besar dari semak belukar. Hal ini disebabkan oleh bahan organik pada hutan lebih besar dari pada semak belukar. Demikian juga dengan kandungan BO pada kebun campuran yang lebih tinggi dibanding hutan dan semak belukar. Jadi, tingginya laju infiltrasi pada kebun campuran dibanding hutan $( \pm 250 \%)$ dan semak belukar $( \pm 398 \%)$ disebabkan oleh dua hal utama, yaitu karena tekstur tanah yang kasar dan kandungan BO nya yang tinggi.

Kandungan bahan organik tanah erat kaitannya dengan vegetasi yang tumbuh pada lahan yang bersangkutan. Ada empat hal pengaruh vegetasi (tanaman) di atas permukaan tanah, yaitu kanopi tanaman dan serasah pada permukaan tanah dapat mereduksi energi kinetik butir hujan, sehingga aggregat tanah bisa terjaga atau tidak rusak. Air hujan yang sampai pada kanopi akan mengalir melalui batang dan mengikuti akar tanaman masuk kedalam tanah. Akar tanaman sendiri berperan membentuk pori makro sehingga jumlah air yang masuk ke dalam tanah bisa lebih banyak dan kemungkinan limpasan permukaan dapat dihindari. Selanjutnya, bahan organik yang berasal dari sisa tanaman, eksudat akar, dan akar yang membusuk, serta akar rambut mampu membentuk dan memantapkan aggregat tanah, sehingga jika dibasahi oleh air hujan aggregat tidak mudah pecah. Dengan demikian, kesempatan infiltrasi lebih besar, kapasitas infiltrasi meningkat, serta aliran permukaan dapat dieliminasi.

Di samping tekstur dan kandungan BO tanah, nilai berat volume (BV) tanah juga mempengaruhi kapasitas infiltrasi tanah. Tanah dengan tekstur yang sama, kapasitas infiltrasinya akan meningkat dengan penurunan nilai BV tanah. Hal ini disebabkan karena pada tanah dengan BV yang rendah berarti tanah tersebut mempunyai ruang pori yang lebih besar dari tanah yang mempunyai BV tinggi. Oleh sebab itu, tanah dengan BV rendah tersebut 

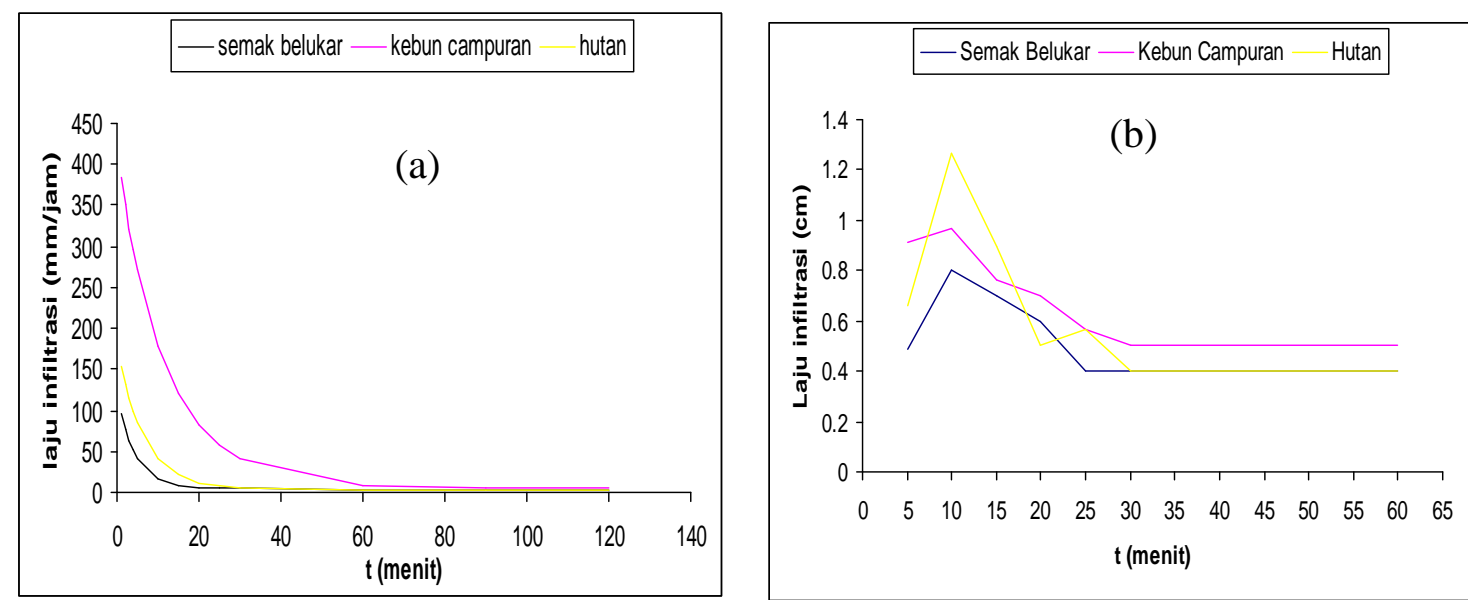

Gambar 2. Laju infiltrasi penggunaan lahan bukit Pinang-Pinang (a) setelah dimasukkan dalam rumus Horton (1940) dan (b) laju infiltrasi nyata

mampu menyimpan air lebih banyak. Diantara tiga penggunaan lahan yang ada, maka kebun campuran mempunyai nilai $\mathrm{BV}$ lebih rendah $\left(0.85 \mathrm{gcm}^{-3}\right)$ dari hutan $(0.91$ $\left.\mathrm{gcm}^{-3}\right)$ dan hutan lebih rendah dari BV tanah pada ekosistem semak belukar $\left(0.96 \mathrm{gcm}^{-3}\right)$ (Yulnafatmawita et al., 2007).

Kumulatif Infltrasi Tanah Pada MasingMasing Penggunaan Lahan

Hasil penetapan kumulatif infiltrasi daerah Pinang-pinang kawasan hutan hujan tropik gunung Gadut Padang dapat dilihat pada Tabel 2.
Berdasarkan Tabel 2 dapat dilihat bahwa kumulatif infiltrasi pada beberapa penggunaan lahan berkisar antara 760 $5204 \mathrm{~mm}$. Keragaman kumulatif infiltrasi ini disebabkan oleh sifat fisika tanahnya dan penggunaan lahan. Penggunaan lahan kebun campuran memiliki kumulatif infiltrasinya lebih besar. Tingginya nilai kumulatif infiltrasi ini disebabkan terutama disebabkan oleh terutama tekstur tanahnya yang kasar, kandungan BO nya yang tinggi, serta nilai BV nya yang rendah. Di samping itu, sistem penutupan permukaan tanah yang rapat dengan adanya understorey plants, berfungsi melindungi permukaan tanah dari tumbukan butir hujan secara langsung dan menahan air dari aliran permukaan, sehingga jumlah air yang memasuki profil tanah meningkat.

Tabel 2. Kumulatif infiltrasi daerah Pinang-pinang kawasan hutan hujan tropik Gunung Gadut Padang.

\begin{tabular}{llc}
\hline No & Penggunaan Lahan & $\begin{array}{c}\text { Kumulatif Infiltrasi } \\
(\mathrm{mm})\end{array}$ \\
\hline 1 & Semak belukar & 759.96 \\
2 & Kebun campuran & 5203.57 \\
3 & Hutan & 1363.38 \\
\hline
\end{tabular}




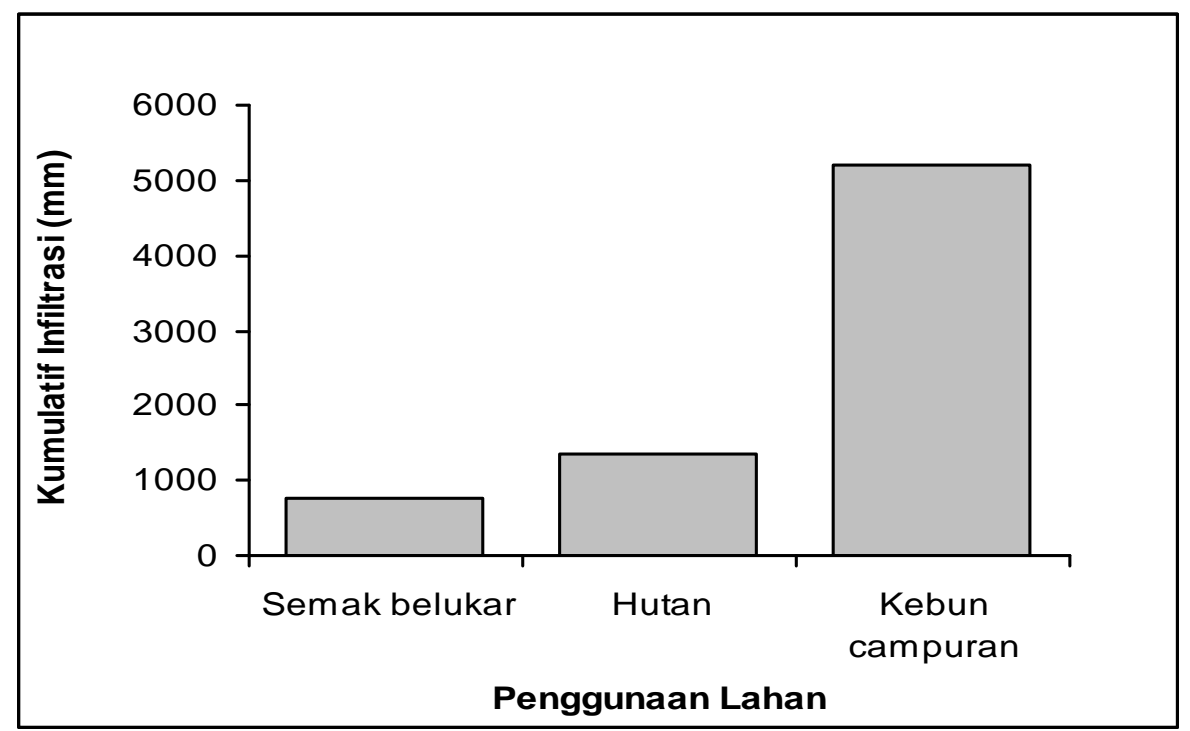

Gambar 3. Grafik kumulatif infiltrasi penggunaan lahan di Bukit Pinang-pinang.

Selain itu, akar, ranting, dan daun tanaman yang mati akan tertimbun menjadi bahan organik tanah yang dapat meningkatkan kumulatif infiltrasi. Dalam tanah, pergerakan akar akan mengubah struktur tanah dan pori-pori tanah, dimana volume perakaran akan mempengaruhi pori makro dalam tanah. Tanah menembus tanah yang padat, kemudian ketika akar mati menyisakan pori makro dalam tanah. Semakin banyak perakaran, maka pori makro akan bertambah sehingga kemampuan tanah dalam menyerap dan menyimpan air juga semakin tinggi.

Berdasarkan kriteria penilaian laju infiltrasi tanah, didapatkan bahwa perubahan penggunaan lahan dari hutan menjadi kebun campuran, dengan adanya understorey plants yang menutupi permukaan tanah, mampu melebihi nilai laju infiltrasi tanah di bawah hutan. Hal ini disebabkan oleh, di samping tekstur tanahnya yang lebih kasar, sangat dipengaruhi oleh kandungan BO tanahnya yang tinggi serta sistem pengelolaan lahannya tidak dilakukan pengolahan. Oleh sebab itu, sejauh ini penggunaan lahan kebun campuran pada kelerengan 3-8\%, tanpa pengolahan tanah, dan permukaan tanah ditutupi oleh tanaman, dari segi laju infiltrasinya, dapat melebihi kemampuan lahan hutan melewatkan air dan menyimpannya dalam profil tanah, setelah lima-puluhan tahun.
Akan tetapi, perubahan penggunaan lahan dari hutan menjadi semak belukar tanpa ditanami, setelah dua puluhan tahun ditebang, menurunkan laju infiltrasi tanah menjadi $62 \%$ nya. Hal ini bukan saja disebabkan oleh lahannya yang miring (slope $>40 \%$ ), tetapi juga oleh teksturnya yang lebih halus dibanding tanah kebun campuran dan hutan, serta BV nya lebih tinggi. Oleh sebab itu, pembukaan lahan hutan tanpa ditanami atau dibiarkan terbuka dan ditumbuhi semak belukar dapat berbahaya bagi kelestarian lingkungan daerah sekitarnya. Oleh sebab itu, pembukaan lahan di daearh berlereng curam $>15 \%$ dan dibiarkan tanpa tanaman menurunkan kemampuan tanah masuk dan tersimpan dalam profil tanah.

\section{KESIMPULAN}

Berdasarkan hasil analisis infiltrasi di laboratorium, perubahan penggunaan lahan di daerah Bukit Pinang-Pinang kawasan hutan hujan tropik G. Gadut Padang, maka dapat disimpulkan sebagai berikut:

1. Perubahan penggunaan lahan dari Hutan menjadi Kebun Campuran, dengan permukaan tanah ditutupi tanaman rendah (understorey plants) dan tanah tanpa diolah, maka setelah 50-tahunan laju infiltrasi tanah 
meningkat dari 154 menjadi 384 $\mathrm{mm}$ jam $^{-1}$ dan kumulatif infiltrasi dari 1363 menjadi $5204 \mathrm{~mm}$.

2. Perubahan penggunaan lahan dari Hutan menjadi Semak Belukar, tanpa ditanami dan diolah, maka setelah 50-tahunan laju infiltrasi tanah menurun dari 154 menjadi 96 $\mathrm{mm} \mathrm{jam}^{-1}$ dan kumulatif infiltrasi dari 1363 menjadi $760 \mathrm{~mm}$.

\section{DAFTAR PUSTAKA}

Hairiah, K., Suprayogo, D., Widianto., Berlian., Suhara, E., Mardiastuning, A., Widodo, R.H., Prayogo, C., dan S. Rahayu. 2004. Alih Guna Lahan Hutan Menjadi Lahan Agroforestri Berbasis Kopi: Ketebalan Seresah, Populasi Cacing Tanah Dan Makroporositas Tanah. hal $68-80$ http://www.worldagroforestry.org/S EA/Publications/files/journal/JA002 0-04.PDF.

Hardjowigeno, S. 2003. Ilmu tanah. Akademik Pressindo. Jakarta. 286 hal

Harto, S. 1993. Analisa Hidrologi. Gramedia Pustaka Utama. Jakarta. 192 hal

Hermansah, Kubota, D., dan Masunaga, T. 2000. Soil quality charac terization in relation to tree spesies diversity in tropical rain forest, West Sumatra, Indonesia I. Comparison of two 1-ha plots. Tropics Vol. 9(2) 133-145.

Hillel, D. 1982. Introduction to Soil Physics. Diterjemahkan oleh Purnomo. R.H. Fakultas Pertanian Unsri Indralaya, 1996. 335 hal

Horton, R.E. 1940. An Approach toward a physical interpretation of infiltration- capacity. Soil Sci.

Soc. Am. Proc. 5, 399-417 hal

Ogiono, K.,.Hotta, M., Tamin, R. dan Yoneda, T. 1984. Forest ecology of gunung Gadut Area. Sumatra Nature Study (Botany, Kyoto.

Lee, R. 1998. Hidrologi hutan. Diterjemahkan oleh Subagio.S. Gadjah Mada University Press. Yogyakarta. 219 hal

Siswanto 2001. Sistem Drainase Resapan Untuk Meningkatkan Pengisian Air Tanah. http://www.unri.ac.id/jurnal/jurnal natur/vol3/5.pdf. Hal 129 - 137

Suprayogo, D., Widianto, Lusiana, B., dan Van Noordwijk, M. 2002. Neraca air sistem agroforestry. cit Hairiah, K., Widianto, Utami, S.R. dan B. Lusiana (eds), WaNuLCAS Model Simulasi untuk Sistem Agroforestry. International Centre for Research in Agroforestry (ICRAF), Bogor, Indonesia. 187 hal.

Wosten, J.H.M., Lilly, A., Nemes, A., and Le Bas, C. 1998. Using existing soil data to derive hydraulic parameters for simulation models in environmental studies and in land use planning. Report 156, SC-DLO, Wageningen (the Netherlands), 106 hal

Yulnafatmawita, Hermansah, dan Amrizal Saidi. 2007. Dinamika Karbon Organik Tanah Bukit Piang-Pinang Kawasan Hutan hujan Tropis Super Basah Gunung Gadut Padang. Laporan Penelitan Fundamental DP2M DIKTI. 